\title{
PALATAL PLEOMORPHIC ADENOMA WITH FLORID SQUAMOUS METAPLASIA: A POTENTIAL DIAGNOSTIC PITFALL
}

\section{Abdul Hakeem Attar, Mandakini B. T, Azhar Fatima}

1. Assistant Professor, Department of Pathology, KBN Institute of Medical Sciences, Gulbarga, Karnataka

2. Assistant Professor, Department of Pathology, KBN Institute of Medical Sciences, Gulbarga, Karnataka

3. Lecturer, Unanai College

\section{CORRESPONDING AUTHOR:}

Dr Abdul Hakeem Attar, C/o Abdul Azeem Attar, Shameem Masala, Attar Gazar, Gulbarga.

Email id- attar.hakeem@gmail.com

\begin{abstract}
:
Pleomorphic adenoma is the most common benign tumor occurring in the major and minor salivary glands. We report a case of pleomorphic adenoma with extensive squamous metaplasia in the palate of a 20 year old man. The dimensions of the tumor were $3 \times 2 \times 2 \mathrm{~cm}$. More than $75 \%$ of the epithelial element in the tumor was composed of sheets of squamous cells, with multiple keratin filled cysts. This case illustrates that pleomorphic adenoma with squamous metaplasia presents a potential for misinterpretation as mucoepidermoid carcinoma and squamous cell carcinoma. We discuss the various pitfalls and the features that are helpful in distinguishing between these lesions.
\end{abstract}

KEY WORDS: Pleomorphic adenoma, Squamous metaplasia

\section{INTRODUCTION:}

Pleomorphic adenoma is the most common benign tumor occurring in the major or minor salivary glands. [1] The tumor is characterized by epithelial and modified myoepithelial elements intermingled with tissue of mucoid, myxoid or chondroid appearance. It has a wide spectrum of morphological patterns, [2] squamous cells, oncocytes, sebaceous cells, bone, adipose tissue and crystalline materials can be found in the tumor. We report a benign salivary gland tumor with a predominant and extensive squamous component. The features are those of a pleomorphic adenoma with florid squamous metaplasia. This case illustrates the difficulty of making a correct diagnosis in the initial tissue specimen and we discuss the diagnostic pitfalls of this pathological entity.

\section{CASE PRESENTATION (CLINICAL DETAILS):}

A 20 year old patient presented with complaint of swelling in the oral cavity since two years. The swelling was painless and progressively increasing in size .Physical examination showed a firm nodule of $4 \times 4 \mathrm{~cm}$ in diameter on the left side of the hard palate and anterior part of soft palate.

Journal of Evolution of Medical and Dental Sciences / Volume 1 / Issue 3 / July- Sept 2012 


\section{CYTOLOGICAL FINDINGS:}

Fine needle aspiration was done and demonstrated some clusters of squamous cells, with some of the cells showing keratinizing cytoplasm .Also seen some clusters of cells with features suggestive of glandular differentiation .Differential diagnosis of well differentiated squamous cell carcinoma \& pleomorphic adenoma was made .

\section{GROSS / HISTOPATHOLOGICAL FINDINGS:}

Surgical resection was done. Gross specimen comprised of well circumscribed, well encapsulated mass, grey white in color and measured $3 \times 3 \times 2 \mathrm{~cm}$. No cystic area, hemorrhage or necrosis was seen .Histological examination showed a well encapsulated tumor more than $75 \%$ of epithelial element in the tumor was composed of squamous cells with multiple keratin filled cysts. The rest of areas showed features of conventional pleomorphic adenoma.

\section{DISCUSSION:}

Histological diversity is the hallmark of pleomorphic adenoma. [3] Histological patterns vary considerably between different parts of same tumor. [3] Focal squamous metaplasia is found in about $25 \%$ of pleomorphic adenoma. Rarely focal squamous metaplasia is reported. [4] Squamous metaplasia is commonly associated with repair following infarction and necrosis of the salivary gland. In the present case necrosis was not seen and squamous cells were detected in FNA biopsy as well as in the resection specimen. squamous metaplasia has been noted in non-neoplastic entities like chronic sialadenitis, necrotizing sialometaplasia, lymphothelial cysts occurring in the vicinity of salivary gland . Potential for misdiagnosis of pleomorphic adenoma as mucoepidermoid carcinoma and squamous cell carcinoma have been reported. In our case also the features misinterpreted as mucoepidermoid \& squamous cell carcinoma. To avoid misinterpretation of pleomorphic adenoma with squamous metaplasia as mucoepidermoid carcinoma on cytology, a close scrutiny for fragments of chondromyxoid stroma - a characteristic feature for pleomorphic adenoma. In our case also on reviewing the slides again after histological diagnosis we could find occasional tiny fragments of stroma. Also keratinization especially of the extracellular type is rare in mucoepidermoid carcinoma. How ever even if the features diagnostic of pleomorphic adenoma are identified, the differential diagnosis may still includes a mucoepidermoid carcinoma arising in a preexisting pleomorphic adenoma.

\section{CONCLUSION:}

We have reported a case of palatal pleomorphic adenoma with florid squamous metaplasia and with potential pitfalls in the diagnosis.

\section{ACKNOWLEDGEMENT:}

The work was indeed a mammoth task to accomplish and would not have been possible without active co-operation, constant strategic support and encouragement by our

Journal of Evolution of Medical and Dental Sciences / Volume 1 / Issue 3 / July- Sept 2012 
beloved - PRESIDENT- (Khaja Bandanawaz Institute of Medical Sciences)—DR.SYED SHAH KHUSRO HUSSAINI.

\section{REFERENCES:}

1. Spiro RH. Salivary neoplasms : overview . Head Neck Surg 1986; 8 :177-84

2. Waldron CA. Mixed Tumor ( pleomorphic adenoma) and myoepithelioma. In : Ellis GL, Auclair PL, Gnepp PR. Eds . Surgical pathology of salivary glands. Philadelphia : Saunders , 1999; 165-86

3. Das DK. Anim JT. Pleomorphic adenoma of salivary glands. Cytopathology $2005: 16$ : 65-70

4. Lam KY, Ng IOL, Chan GSW. Palatal pleomorphic adenoma with florid squamous metalasia . J Oral Pathol Med. 1998; 27: 407-10. 


\section{CASE REPORT}

Fig 1- Photograph showing swelling in the palate

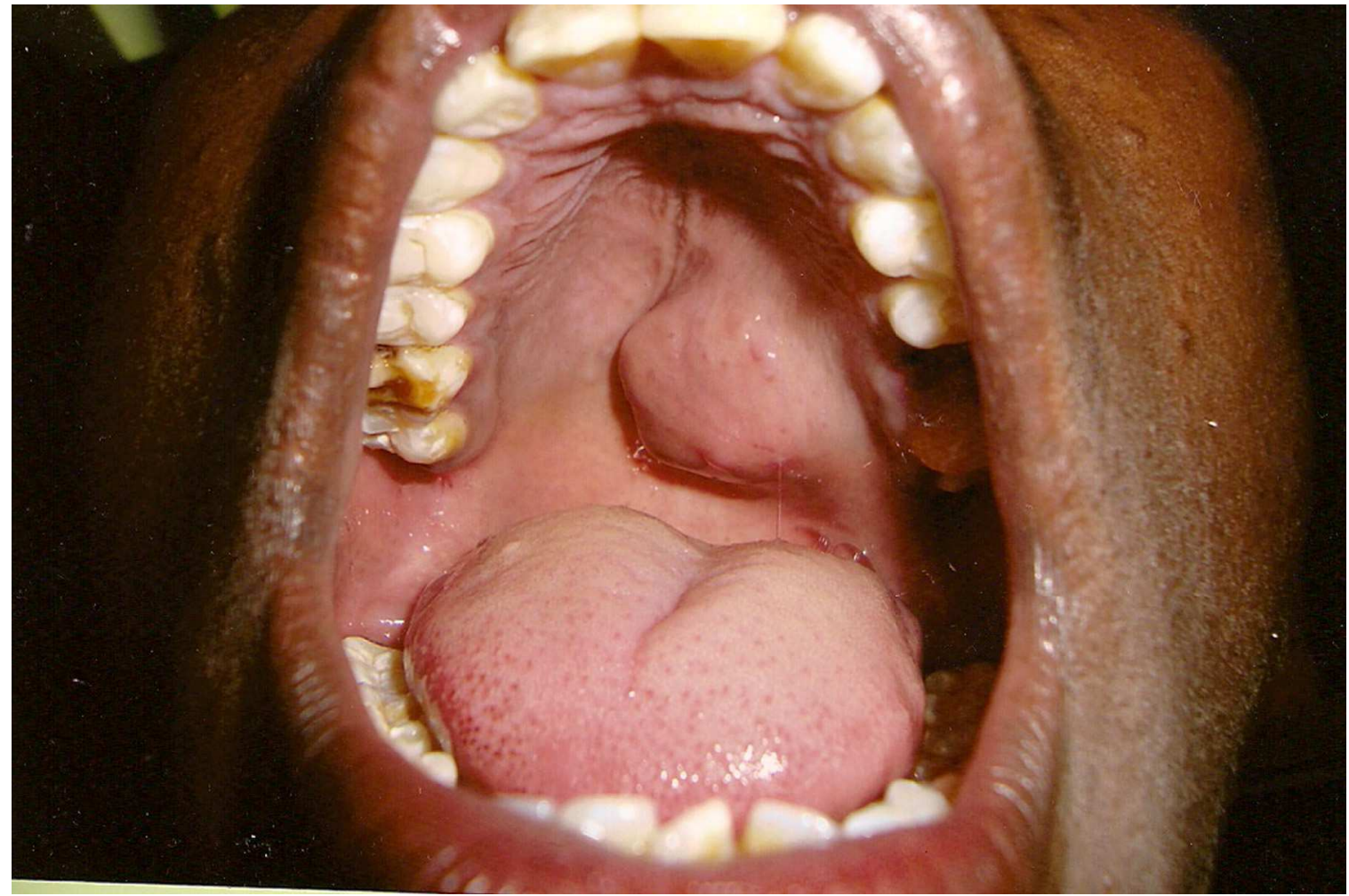

Fig 2- Gross photograph showing well circumscribed tumor

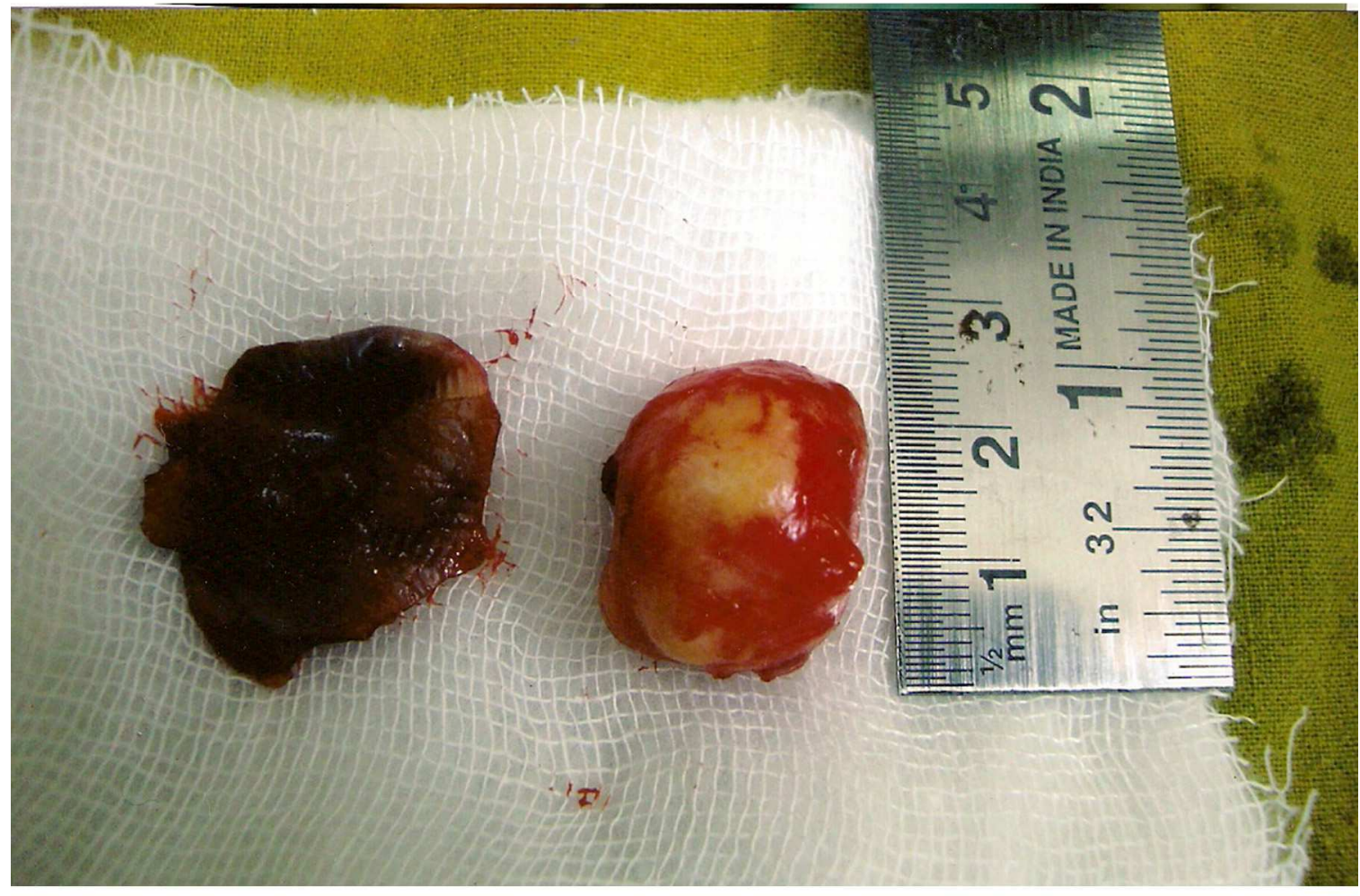

Journal of Evolution of Medical and Dental Sciences / Volume 1 / Issue 3 / July- Sept 2012 


\section{CASE REPORT}

Fig 3- Photomicrograph showing squamous cells with keratin pearls. (H\&E, 400X)

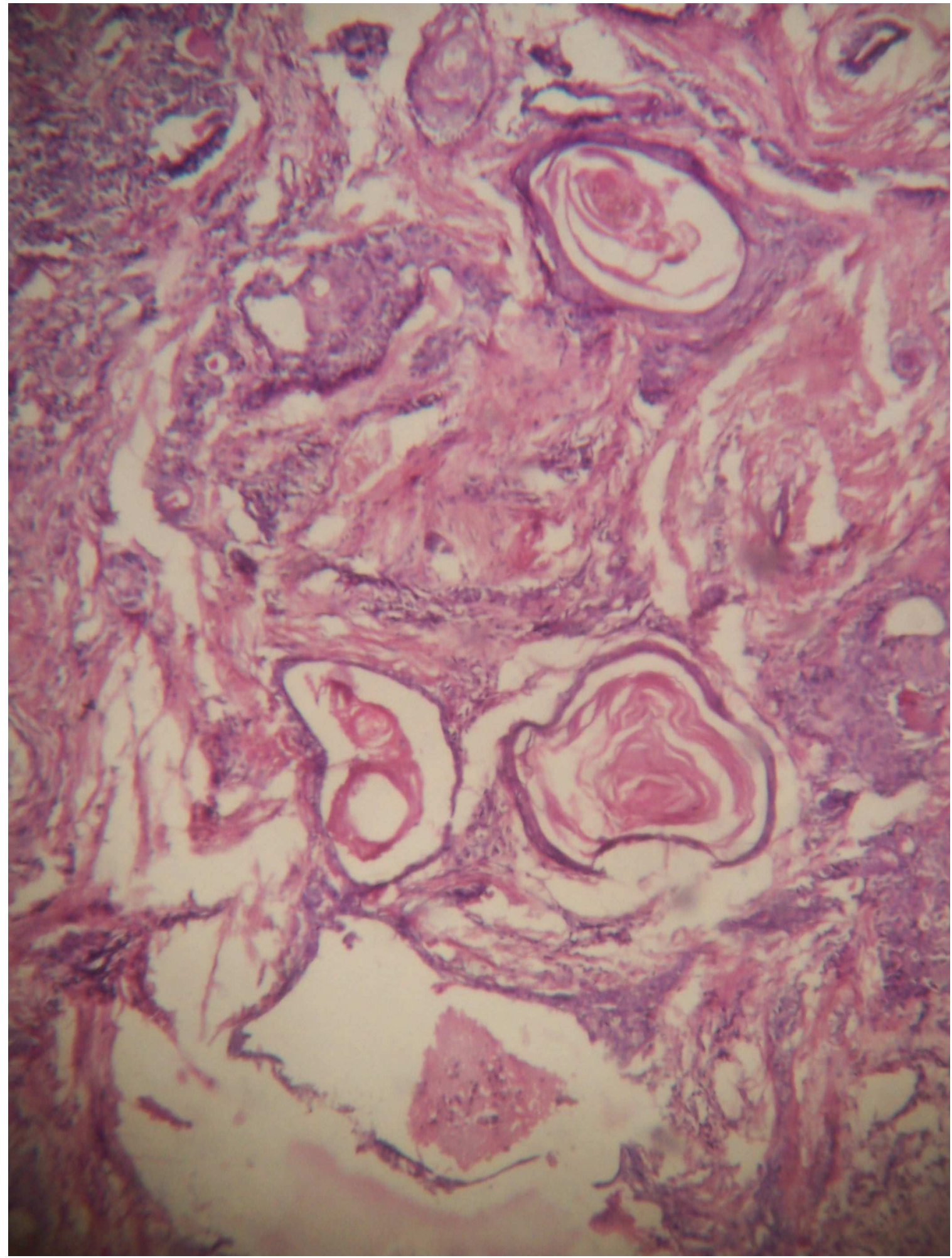

Journal of Evolution of Medical and Dental Sciences / Volume 1 / Issue 3 / July- Sept 2012 


\section{CASE REPORT}

Fig 4- Photomicrograph showing conventional pleomorphic adenoma (H\&E, 400X)

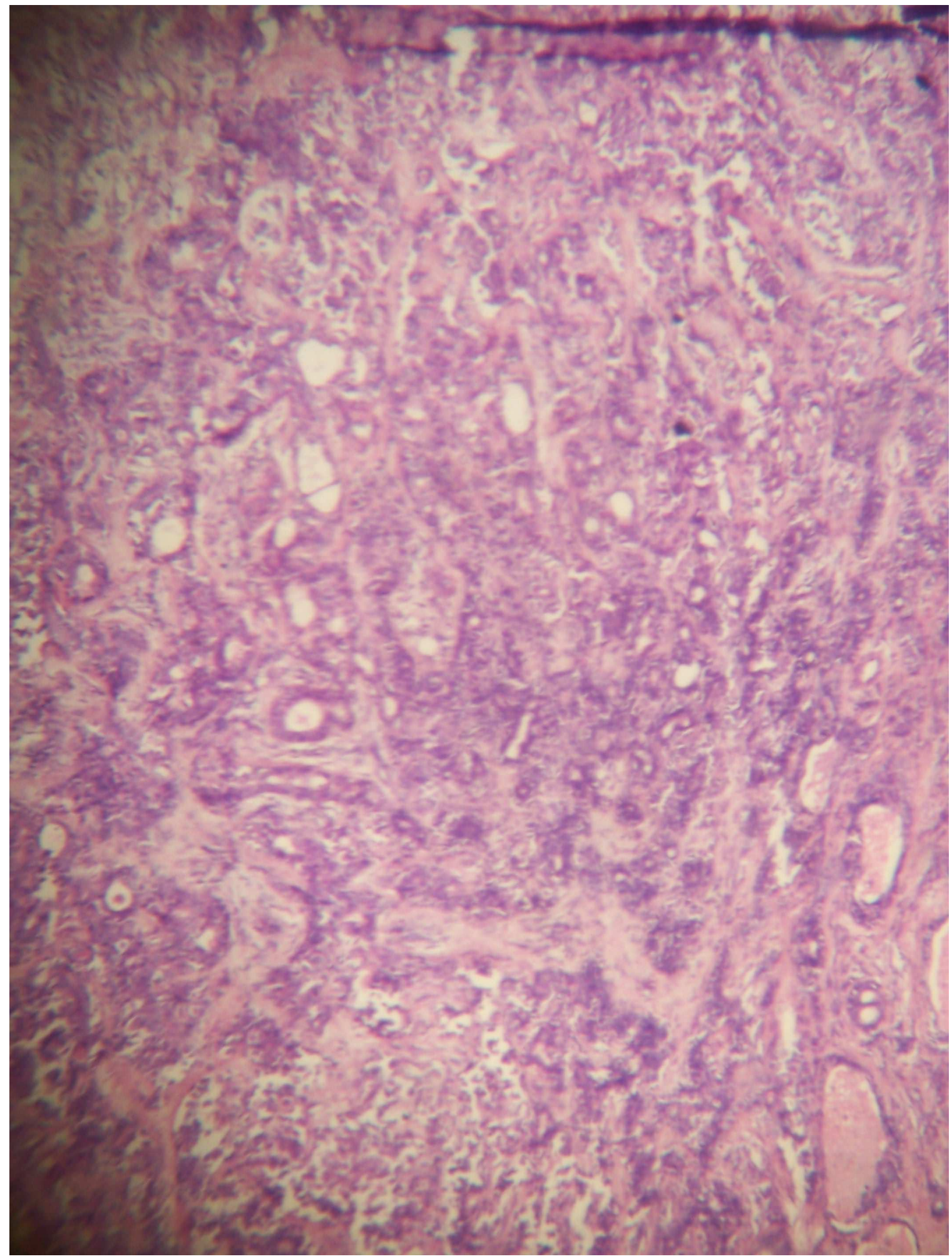

Journal of Evolution of Medical and Dental Sciences / Volume 1 / Issue 3 / July- Sept 2012 